\section{Visión Electrónica \\ Más que un estado sólido}

http: revistas.udistrital.edu.co/ojs/index.php/visele/index

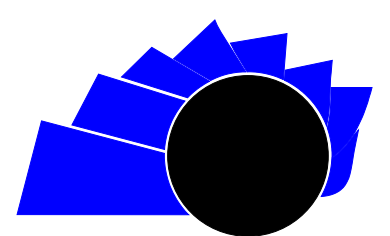

VISIÓN ELECTRÓNICA

\title{
Image analysis aplications in precision agriculture
}

\author{
Aplicaciones de análisis de imágenes en agricultura de precisión
}

Wilson Fernando Moreno ${ }^{1}$, Héctor Iván Tangarife. ${ }^{2}$ Andrés Escobar Díaz. ${ }^{3}$

INFORMACIÓN DEL ARTÍCULO

Historia del artículo:

Enviado: $12 / 10 / 2016$

Recibido: $22 / 02 / 2017$

Aceptado: 23/06/2017

\section{Keywords:}

Aerial photography

Agricultural applications

Precision agriculture

UAV

\section{Open access

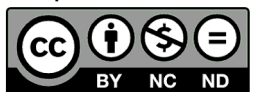

Palabras clave:

Fotografía aérea

Aplicaciones agrícolas

Agricultura de precisión

UAV

\begin{abstract}
Unmanned Aircraft Vehicles (UAVs) are currently used for multiple applications in various fields: forestry, geology, the livestock sector and security. Among the most common applications, it is worth to stand out the image acquisition, irrigation, transport, surveillance and others. The study that one presents treats of the implementations that are realized by means of aerial images acquired with UAVs directed to the farming. Images acquired until recent years had been using satellites, however due to the high costs that are incurred and low accessibility to these technologies, UAVs, have become a tool for greater precision and scope for making decisions in agriculture. Information from databases of international magazines, groups and research centers is taken to determine the current state of implementations in Precision Agriculture (PA). This article describes tasks such as: soil preparation; limits and land areas, vegetation monitoring; classification of vegetation, growth, height, plant health; diseases management, pests and weeds, fertilization and inventory developed from analysis of aerial images acquired with UAVs.
\end{abstract}

\section{RESUMEN}

Los vehículos aéreos no tripulados (UAV) se usan actualmente para múltiples aplicaciones en múltiples campos: silvicultura, geología, sector ganadero y seguridad. Entre las aplicaciones más comunes cabe destacar la adquisición de imágenes, el riego, el transporte, la vigilancia, entre otros. Las imágenes adquiridas hasta los últimos años han estado utilizando satélites, sin embargo, debido a los altos costos que se incurren y el bajo acceso a estas tecnologías, los UAV se han convertido en una herramienta para mayor precisión y alcance para la toma de decisiones en la agricultura. La investigación que se presenta, trata de las implementaciones que se realizan mediante imágenes aéreas adquiridas con UAVs dirigidas a cultivos. La información de las bases de datos de revistas internacionales, grupos y centros de investigación se toma para determinar el estado actual de las implementaciones en Precision Agriculture (PA). Este artículo describe tareas tales como: preparación del suelo; límites y áreas de tierra, monitoreo de vegetación; clasificación de la vegetación, crecimiento, altura, estado fitosanitario; manejo de enfermedades, plagas y malezas, fertilización e inventarios desarrollados a partir del análisis de imágenes aéreas adquiridas con UAVs.

\footnotetext{
${ }^{1}$ BSc. In control engineering, and Electronic Technologist: IMS Communications S.A.S, Colombia. E-mail: wilson.moreno@imscomunicaciones.com, wilson.moreno.ext@claro.com.co

${ }^{2}$ BSc. In control engineering, and Electronic Technologist: Universidad Distrital Francisco José de Caldas, Colombia. Current position: Instructor research SENA. E-mail: hitangarife@misena.edu.co.

${ }^{3}$ MSc. In Engineering, and MBA, Universidad de los Andes, Colombia. Current position: Professor Universidad Distrital Francisco José de Caldas, Colombia. E- mail: aescobard@udistrital.edu.co.
} 


\section{Introduction}

Precision agriculture (PA) aims to collect information to estimate variable importance in the field to perform a localized management also called Site-Specific Management (SSM). The PA is based on an agricultural holding depending on the needs of each hardiness zone [1]. The last goal is to assess the conditions of an area to make appropriate use of resources [2], reduce pollution [3] and increase efficiency [4]. On the other hand, UAVs are a tool that has been used for applications in various fields; forest engineering, geology, agriculture, in this last, it is mainly used in applications foimages that have traditionally been done by satellite, It is noteworthy the ability to operate at low altitudes [5] and at any time [6], execute tasks without human pilot [7] allow dangerous work and help to access impossible areas to reach [8]. The review that is shown below finds the UAVs as a tool for the acquisition of aerial images at different stages of the production process, applications made by photo-interpretation are studied and organized as follows: site preparation [9], size, boundary and use of area [10] crop monitoring [11,12], plant health [13], detection of nutritional stress $[14,15]$, detection of water stress [16], evaluation of inventory [17], change in land use [14]. The main contribution of this paper is to discuss current applications, the potential use in the country, the challenges and the future direction of technology development directed to the agricultural sector.

\section{Precision Agriculture}

Precision agriculture (PA) starts from the technology transfer in different sectors such as industry and militia towards the agriculture in response to the need to modernize production systems and give a proper management to the crops, for the replacement of conventional work based on statistical averages and generalizations in field. Conventional management is characterized by inefficient use of inputs that as result generate pollution and decline in performance and production system. The new concepts of agriculture propose a management of a specific site [18], which should use the necessary inputs in the required amount, the right place and the right time [19]. Recently, there emerge tools that help in decision-making, its development is based on electronic technology (telecommunications and computing), enabling collect, store, process, transmit and retrieve information in the field [20]. Among these tools, there are the UAVs, whose main application is remote sensing where an image for subsequent interpretation and analysis is acquired, from it, is possible to identify objects of interest through color, by using temperature as a means of obtaining information and quantifying of biological variables to identify anomalies in crops [21]. From the information provided can be made applications of inputs or weed management in specific places, in the quantities required, at the appropriate time as is posed by the new concept of precision agriculture.

\section{Applications of UAVs in the agricultural sector through photo interpretation}

The use of UAVs are wide depending on factors such as: payload capacity [22], which allows making applications focused on irrigation [23], the transport of personnel or entrusts [24]. Nevertheless, aerial images provide a wider range of applications in other areas, it is noteworthy that in architecture and civil engineering are used to perform prior models to the implementation of a construction $[25,26]$ in film industry are used to film [25], and in forestry engineering allow to make environmental studies to characterize ecosystems [27]. However, UAVs have a great potential of usage in agriculture as an alternative for the solution of multiple problems, these are presented through the production cycle from the soil preparation to harvest, in principle, the process requires to make a planning of the production system, taking into account geography and area distribution according to needs, parallel to crop development there are environmental states that make the process be susceptible to external agents conditions such as competition with other plants called weeds, [28], [29] which they weaken a crop and make it very responsive to the condition caused by pests or diseases. Remote sensing is part of a solution that uses analyzed variables by using digital photography for decision-making, some situations that can be handled are related to soil preparation [30-32], inventory [28], [33], monitoring crop development, distribution of variables in field as diseases, weeds, nutritional deficiencies, cover classification, irrigation and others. Soil preparation is done [30], cadastral boundaries, crop area (size, shape, border and use) are determined, as indicated by several studies [30-32]. Vegetation is monitored [23,30,31,34,35]. Tree height (growth) [35, 35]. Coverage classification $[29,31,33]$. With regard to plant health $[30,33]$ three aspects are studied using aerial photography: weed management $[28,29]$ pest and disease depending on the condition of the pathogen in the plant. Fertilization [37] is an issue that is studied based on color changes that leaves or other organs have because of nutritional deficiencies.

On the other hand, inventory assessment as stated by $[28,30,33]$, in the livestock sector is important; 
it is generally used to count animals and plants as livestock or fruit trees, row count, for example corn, rice or cane for determining amounts through sowing densities, in addition, it is studied the thermal photo interpretation [9], to applications in sophisticated systems [38]. The products obtained from studies are ortophotos [30], digital surface model [9, 34, 36, 39, 40] Digital Elevation Models (DEM) [30,38] and Digital Terrain Models (DTM) [30]. The following describes each of the applications:

\section{Preparation of the land}

Planning a production project requires the study of planting area, and the remote sensing recently emerged as a mapping tool to describe location, size and use among other applications [41] in agriculture these applications allow to determine the area to be planted, also limits, crop type, location of susceptible points and future management, for example, timely entry and exit of water resources, provides good nutrition and health to the cultivation conditions, thereby, leveling land serves to maintain a good system of irrigation and drainage.

UAVs are currently used in topography, to quickly and independently acquire the data mapping in three dimensions, to plan a photogrammetric flight and its execution to generate $3 \mathrm{D}$ point clouds from mobile digital images [42], Figure 1 below, shows the technique and modeling, the results allow to take measures in order to carry out land movements for leveling, irrigation and drainage planning. The importance is presented at the beginning of the production process, generally, the production area requires to accommodate the field planting, seeking to ensure optimal conditions for future use of the resource and management of diseases and weeds; the experience with UAVs developed in these topics are useful for research and implementation in agriculture [43]. More recently, these techniques have been implemented in forestry and it is related to the change of use of land from the impact of soil erosion in watersheds, through remote sensing [44].

Figure 1: Technique of acquisition of image and reconstruction of $3 \mathrm{D}$ model with depth [42].

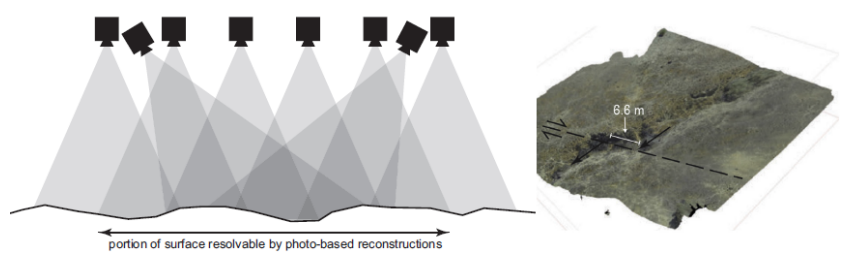

4.1. Cadastral boundaries, crop area (size, shape, border and Uses)

From a geo-referenced image of good resolution that uses tones variations in luminance between white and black in a Photo can be determined: the area of production, forest and cultivated vegetation cover, and the land uses [45], the boundaries of an area can be obtained by differences in light absorption as shown in Figure 2, the forest and crops have light and dark tones respectively and water an intermediate tone between the two, those differences in an image are used for planning the area and the crop projection with the purpose to define what to plant and how to distribute.

Figure 2: Difference of tones in an area [45].

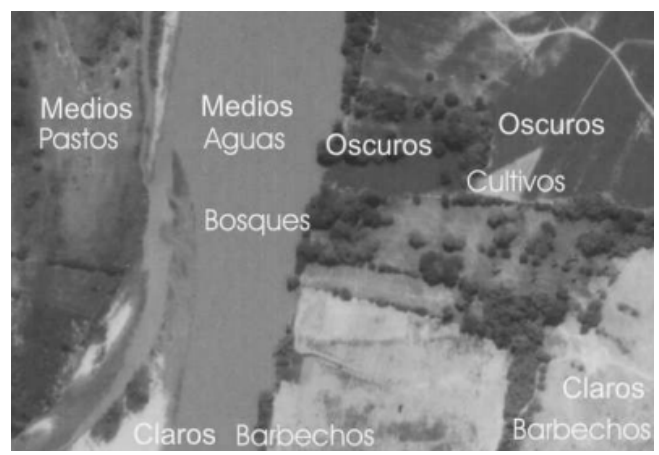

\subsection{Monitoring of crops}

Monitoring is the observation of parameters to supervise and control, the use of multiple small scale UAVs in order to respond to other flying devices. It has become very popular due to the low costs, these UAVs are used for real-time monitoring, by merging multiple images of airborne sensors, in Austria, they have focused on developing methods to improve the quality of registration for real-time monitoring and mobile mapping, the method provides descriptors to identify regions and to record depth maps that determine the growth reasons and differences in height of vegetation [46]. Images from different sensors (visual and thermal) they can provide additional information for monitoring purposes.

The correct location on a map and proper fusion of information from different spatial and temporal locations depends on the georeference, in the agricultural sector is useful to perform automatic sampling, researchers propose a method for automatic georeference of images obtained from UAVs, the technique provides constant reviews of the position; based on a set of data, these 
techniques are useful to monitor and sample large areas [47]. It is also used in monitoring the phenolic maturity and determination of crop vigor with Normalized Difference Vegetation Indexes (NDVI) [48]. Through images from conventional RGB cameras using UAVs are also obtained georeferenced orthophotos, in order to characterize the main parameters of plant growth for the management of irrigated crops in semiarid conditions. High resolution images obtained with UAVs in conjunction with the right treatment can be a useful tool, particularly in Precision Agriculture to control the plant growth and its development, and to advise farmers on water requirements, control of weeds and insect pests, among others $[49,50]$.

The main application of the Fraction of Intercepted Photosynthetically Active Radiation (FIPAR) is not only related to the adjustment to the actions of management and collection in homogeneous areas within the field, it is also used for determining orientation of the row and percentage of coverage. The model was tested in peach and citrus from commercial orchards. Simulations suggest the usefulness of these modeling methods in structured orchards [51]. On the other hand, the Leaf Area Index (LAI) is involved in biological, environmental and physiological processes that are related to photosynthesis, transpiration, interception of radiation balance and energy. The LAI is critical to characterize the growth and development of crops. The estimation of Green Canopy Coverage (GCC) may benefit from aerial observation, since can be measured by image analysis or be estimated by obtaining different vegetation indices. The aim is to study the relations between the GCC and LAI using aerial images in order to characterize the growth in corn and onion [49]. Multispectral remote sensing is a non-destructive method for monitoring the state of vegetation of vines to produce grapes and wine of high quality, new techniques to evaluate the spatial distribution of vigor and maturity have been applied to different varieties. For example, the mapping of the Normalized Difference Vegetation Index (NDVI) is obtained by a high-resolution camera mounted on an UAV, with it the spatial variability of the content of anthocyanins in situ [48] grape is detected.

\subsection{Plant health}

The photography that allows control weeds is taken by the UAV to detect patches and make the application to the required places and in the quantities strictly necessary, investigations propose a system equipped with a multi-spectral camera which can acquire images in time and desired locations, a ground station with interface between the operator and the UAV for planning is available, the system is used to manage the application of glyphosate for weed control [52]. The NDVI is calculated, so, red color represents the weed force, blue means bare soil, and yellow is emergency. Images from the figure 3 next page, are generated. August 2nd corresponds to a day after application of glyphosate, until September 16 th no weeds, and in September 4th it is observed weed emergence.

The overall application of pesticides to control weeds or diseases is crucial in agricultural areas, application in the areas of interest helps in improving performance. Generally, conventional agriculture does not consider factors that reduce yields, such as loss of inputs in areas of non-crop. Researches propose to take into account the climatic conditions such as strength and wind direction to avoid loss of inputs caused by wind drift, and the overlap in places already applied, To do this, an auto-adjust algorithm for routes under different conditions is performed by sensors network and it is run on a UAV, the model shows that the setting can significantly reduce the loss of pesticides and fertilizers [53].

The management of early weed in site-specific of broadleaf in a wheat field can be performed by orthomo-

Figure 3: a. One day after application, b. no weeds, c. new patches [52].

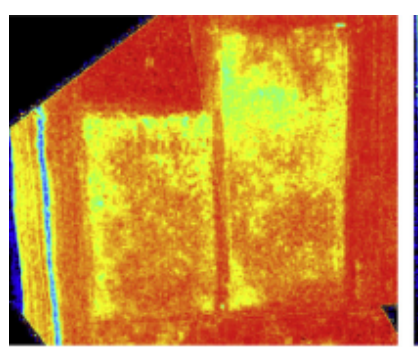

a Aug. 2nd, 2007

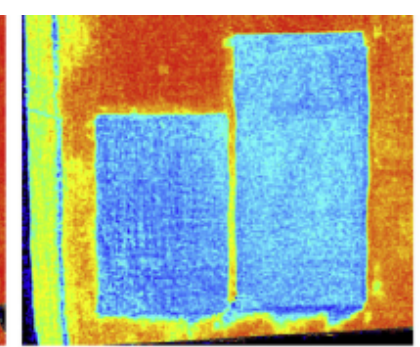

b Aug 16th, 2007

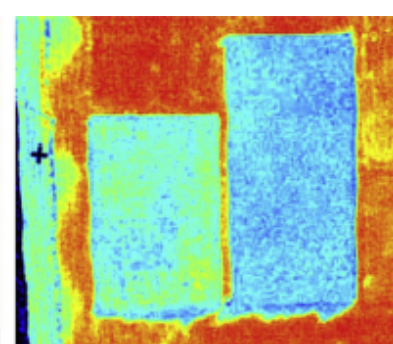

C Sep. 4 th, 2007

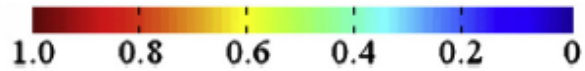


saics [54]. The use of high spatial resolution images taken by aerial vehicles is studied, these images have shown having the potential for controlling agronomic and environmental variables. A large number of captured images is done to be superimposed and form a mosaic that produces a single image representing the whole of the work area. The work provides a solution to large sampling areas to control of weeds.

Some diseases are manifested in the crops by chlorotic spots, leaf deformations or signs of powdery appearance on the upper or lower side of the leaf [55], one of the diseases that generates great economic limitations is the mildew, caused by a forced fungus, the symptoms appear as chlorotic spots on the leaves, which can progress until causing leaf necrosis.

Studies have shown that the use of images of high thermal resolution and multispectral can be an indicator of infection, in Figure 4 below, it is shown a project that was conducted in two poppy plots artificially infected. The thermal and multispectral images were acquired with a resolution of $200 \mathrm{~mm}$ in three dates by an UAV [56]. The work shows the feasibility to detect the disease through aerial photography based on a high correlation between the presence of the disease in field and the identification in images.

\subsection{Detection of nutritional stress}

Problems related to the scarcity of fertilization manifest themselves in different forms such as leaf yellowing, stunting, necrosis, as seen in Figure 4, these variations can be monitored by remote sensing.

Figure 4: Symptoms nitrogen deficiency [57].

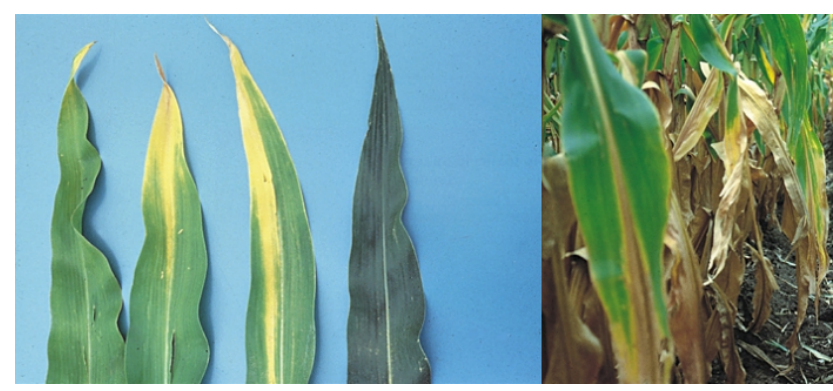

Applications of UAVs in Precision Agriculture covers the design of requirements fertilizer, which can be performed by using multi-spectral cameras or common cameras with specific filters to estimate the Vegetation Index (VI) [58]. The use of aerial photography by UAVs helps determine the VI that relates crops own variables such as nutritional deficiencies algorithms for doses of fertilizer in plants. Figure $\mathbf{5}$ shows an experiment conducted in corn in two different pieces of land, one under controlled fertilization and the other with traditional management, it were determined the VI, NDVI and LAI, results show that fertilization decision is based on various parameters: leaf area, leaves color, biomass, and others; studies show a high correlation between the images studied and nutritional deficiencies according to the leaf color.

Figure 5: Orthorectified mosaic. The inset delimits the corn fertilization test. Red circles stand out the cultivation areas measurement [58].

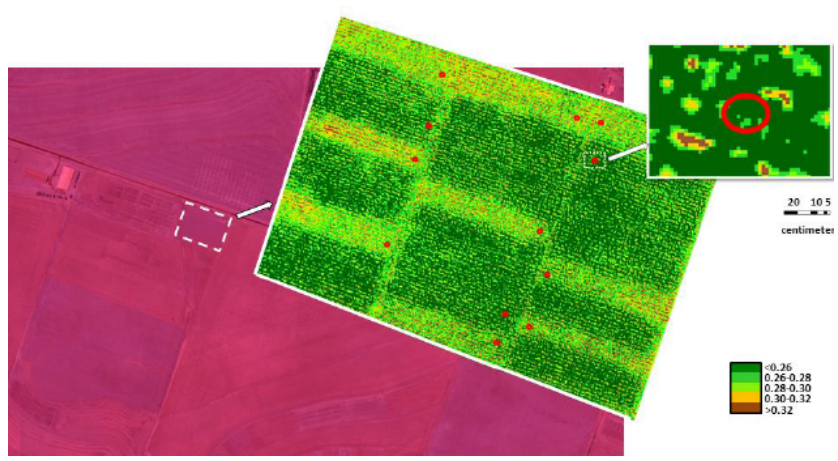

On the other hand, it is known that the phenotype is the set of visible characters on individuals, so the remote sensing based on UAVs can also be used rapidly and profitably to identify phenotypes. Currently, it equipped with sensors for the formation of multi-spectral images for spatial variability of soil nitrogen and subsequent phenotyping for low nitrogen (low N) and tolerance of corn to nitrogen stress is evaluated by the Normalized Difference Vegetation Index (NDVI) [59].

The NDVI is calculated for generating useful information for applications in precision agriculture techniques, from there, the affinity is studied with several indexes that relate the state of the crop, in another study, the used vehicle has a multi- spectral sensor that acquires multitemporal images during the sunflower growth, those measurements are taken at different times of the day. The results showed that the linear regressions between NDVI and grain yield, aerial biomass and nitrogen in biomass were significant at the $99 \%$ of the confidence level, except during the very early stages of growth, but the time of day where images are acquired, the process classification and image resolution did not have effect on the outcome [60].

In Italy, they use unmanned aerial vehicles to obtain aerial photographs of vineyards. The information 
between rows and characterization of the vineyard serve to map the plant vigor, it also can be used to reference other tasks of viticulture as path planning of unmanned ground vehicles [61]. Additionally, it is proposed the use of aerial platforms for researching on issues related to land allocation, physiological traits in crops, including the response to biotic and abiotic stresses.

\section{Valuation of Inventory}

Inventory has recently been used in forestry, to determine quantity and state of health of both urban and rural trees, to acquire information about inventory of roads and their status, and in the livestock sector it is often required to count and monitor animals, studies scans of large areas of livestock systems as shown in Figure 6.

Figure 6: Detection of cattle in livestock systems [62].

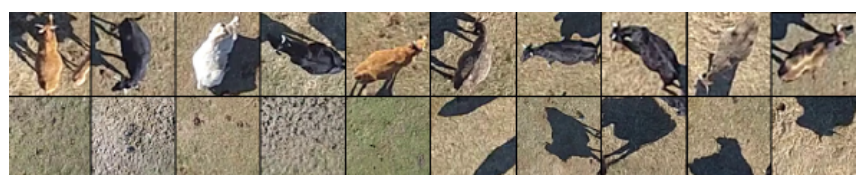

Counting and monitoring of animal species can be done by video recordings taken from UAVs. The system also keeps track of the number of animals identified (Figure 7).

Figure 7: Detection of cattle in livestock systems [62].

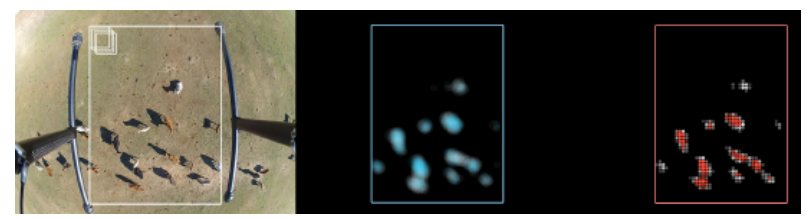

In the agricultural sector, they are made inventories about the amount of trees, for example: fruit trees, rows of products with high density planting, and irrigation systems; the applications depend on the needs that might arise in field.

\subsection{Detection of water stress}

Producers with areas of considerable size, in which the water management is difficult because of the acreage, they have made more technical the production system through the implementation of drip irrigation, which are used in order to optimize the use of water resources.
There are two ways to identify the good or bad running of the system, the first relates to the identification of faults and the second with the plant water stress manifested in physical characteristics as a source of information, so, thermography is a useful tool to identify the proper functioning or failures that may occur in irrigation systems.

It has been developing since 2002 applications for monitoring and decision supporting by using solar energy UAVs, from them aerial shots are made and color images are used to map invasive weeds outbreaks and reveal anomalies in irrigation and fertilization [63].

By using photography it is possible to find differences in temperature in the productive system, it is common to find lower temperatures in places where leaks are present while irrigation is running, this is an efficient way to identify and correct failures in extensive irrigation systems, supporting this methodology, the implementation status of the resource can be evaluated based on temperature measurements of the foliage of treetops in individual trees, when the system is active such as fruit production; the study results show it is feasible to use high-resolution thermal images for the integration of crops response in evaluating the performance of irrigation and to provide recommendations [64].

On the one hand, researches propose thermal images taken by UAVs to evaluate the correlation of the canopy temperature and water status of the plant, allowing to determine the situation of supply systems, which may not always be easily detected with standard testing irrigation protocols performance [65]. On the other hand, water stress can also be measured based on canopy temperature and vapor pressure deficit, usually it is used for the irrigation diagnosis the indicator maps of Crop Water Stress Index (CWSI), currently used to detect the spatial variability of water deficits through grape crops, thermal images obtained by UAVs have been effective in evaluating the spatial variability of water scarcity [66].

Color is also an indicator of water stress, for instance, in Spain have been carried out experiments to determine measurements of chlorophyll fluorescence in leaf and index data of reflectance in citrus, working under a controlled deficit irrigation [67]. The data consists of thermal and hyperspectral images acquired at the time of maximum tension, before the step of re-watering. The study demonstrates the feasibility of the thermal and narrow band indices, and fluorescence recoveries obtained from a hyper-spectral micro camera and a thermal imaging camera on board small UAV platforms 
for detection of stress in the foliage of trees [68]. Thermal and multispectral images allow evaluation and mapping of the spatial variability of crop water status [69].

\subsection{Changing land use}

The change in land use is done to expand the agricultural frontier or to restore an area through reforestation, from the agroecologically point of view, researchers evaluate whether measurements of lightweighted Unmanned Aerial Vehicles (UAVs) are profitable replacement for traditional field measurements, and to determine the structure of the foliage in forest restoration studies. The method combines aerial images from digital cameras with computer vision software to generate 'point cloud' 3D models of vegetation at high spatial resolutions.

These methods could broaden the scope of the studies about dynamics and forest recovery when combined with calibration over field [70].

\section{Conclusions}

Agriculture can be seen highly benefited in economic and environmental terms on the basis of identification of site-specific variables that can provide solutions to traditional problems of indiscriminate applications by averages or planned, by both spatial and temporal monitoring that provides reliable information for a better understanding of the crop dynamics.

The resource optimization can significantly increase the performance of the production system for two reasons: first, production increases due to the rigorous spatial management in the productive system, and secondly, there is a decrease in the quantity of inputs (fertilizers, herbicides and others) as well as a consequent reduction of costs, this ratio significantly increases the rate of inputs regarding the outputs (cost-benefit).

Aerial photography by UAVs brings great benefits, both technical and economic. Firstly, it can identify field variability by a specialized software, and secondly, photography with UAV is more accessible for farmers than satellite images in terms of money.

Colombia has great potential for UAVs using, because of being a country with a primary production, but geography is a limiting factor that must be taken into account for the implementation of new technologies. Other perspectives and current trends can be consulted on the web, oriented to networks of specialists in the subject, see among many: for example [71].

\section{References}

[1] F. López, "Uso de Vehículos Aéreos no tripulados ( UAV ) para la evaluación de la producción agraria" Ambient. Agric. precisión, pp. 40-52, 2013.

[2] S. Cox, "Information technology: The global key to precision agriculture and sustainability," Comput. Electron. Agric., vol. 36, no. 2-3, pp. 93-111, 2002. https://doi.org/10.1016/S0168-1699(02) 00095-9

[3] A. S. Danilov, U. D. Smirnov, and M. A. Pashkevich, "The system of the ecological monitoring of environment which is based on the usage of UAV," Russ. J. Ecol., vol. 46, no. 1, pp. 14-19, 2015. https: //doi.org/10.1134/S1067413615010038

[4] B. S. Faiçal, G. Pessin, G. P. R. Filho, A. C. P. L. F. Carvalho, G. Furquim, and J. Ueyama, "Fine-tuning of UAV control rules for spraying pesticides on crop fields," IEEE, 2014.

[5] Y. Motor, "Yamaha unmanned helicopters," Yamaha Australia Sky Division, p. 8, 2014.

[6] K. Uto, H. Seki, G. Saito, and Y. Kosugi, "Development of uav-mounted miniaturure hyperspectral sensor system for agricultural monitoring," 2013 IEEE Int. Geosci. Remote Sens. Symp. - IGARSS, pp. 4415-4418, 2013. https ://doi.org/10.1109/IGARSS . 2013.6723814

[7] Y. Saleem, M. H. Rehmani, and S. Zeadally, "Integration of Cognitive Radio Technology with unmanned aerial vehicles: Issues, opportunities, and future research challenges," J. Netw. Comput. Appl., vol. 50, pp. 15-31, 2015. https://doi.org/10. $1016 / j \cdot j n c a \cdot 2014.12 .002$

[8] A. Sato and H. Naknishi, "Observation and measurement in disaster areas using industrial use unmanned helicopters," 2014 IEEE Int. Symp. Safety, Secur. Rescue Robot., pp. 1-5, 2014. https: //doi.org/10.1109/SSRR. 2014.7017671

[9] G. Bareth, "Use of drones in agriculture - prospects and limitations," Plantekongres, p. 90, 2014.

[10] E. Salamí, C. Barrado, and E. Pastor, "UAV Flight Experiments Applied to the Remote Sensing of Vegetated Areas," Remote Sens., vol. 6, no. 11, pp. 11051-11081, 2014. https://doi.org/10.3390/ rs61111051

[11] D. Anthony, S. Elbaum, A. Lorenz, and C. Detweiler, "On Crop Height Estimation with UAVs," IEEE, pp. 4805-4812, 2014. https://doi.org/10. 1109/IROS. 2014.6943245 
[12] T. Arnold, M. De Biasio, A. Fritz, and R. Leitner, "UAV-based measurement of vegetation indices for environmental monitoring," Proc. Int. Conf. Sens. Technol. ICST, pp. 704-707, 2013. https://doi. org/10.1109/ICSensT . 2013.6727744

[13] F. Ay and B. Bili, "Insansiz Hava Araci ile Tarimsal ilaclama Application of Pesticide Using Unmanned Aerial Vehicle," no. 2130187, pp. 0-3, 2015.

[14] E. A. George, G. Tiwari, R. N. Yadav, E. Peters, and S. Sadana, "UAV systems for Parameter Identification in Agriculture" IEEE, https://doi. org/10.1109/GHTC-SAS. 2013.6629929

[15] B. P. L. Hollis, B. J. Hart, A. Austin, and R. Clover, "North Carolina to test UAV use in agricultural production," vol. 42, no. 9, pp. 6-9, 2015.

[16] J. J. Berni, P. P. J. Zarco-tejada, L. Suarez, E. Fereres, S. Member, and L. Suárez, "Thermal and Narrowband Multispectral Remote Sensing for Vegetation Monitoring From an Unmanned Aerial Vehicle," IEEE Trans. Geosci. Remote Sens., vol. 47, no 3, pp. 722-738, 2009. https://doi.org/10. 1109/TGRS. 2008.2010457

[17] D. Bannett, "What are key UAV issues for agriculture?," South east farm press, p. 2, 1990.

[18] R. Bongiovanni and J. Lowenberg-Deboer, "Precision agriculture and sustainability," Precis. Agric., vol. 5, no. 4, pp. 359-387, 2004. https:// doi.org/10.1023/B:PRAG.0000040806.39604.aa

[19] F. R. Leiva, "La agricultura de precisión: Una producción más sostenible y competitiva con visión futurista," VIII Congr. la Soc. Colomb. Fitomejoramiento y Prod. Cultiv, November, 2003.

[20] K. Thorp, "Encyclopedia of Remote Sensing: Precision agriculture article," Precis. Agric., 2014. https://doi.org/10.1007/s11119-012-9274-5

[21] C. Zhang and J. M. Kovacs, "The application of small unmanned aerial systems for precision agriculture: A review," Precis. Agric., vol. 13, no. 6, pp. 693-712, 2012.

[22] Yamaha, "Yamaha Helicopter Tipo II G / tipo II," may 12 th 2015. [Online]. Available: http://rmax. yamaha-motor.com.au/

[23] J. Gago, C. Douthe, R. E. Coopman, P. P. Gallego, M. Ribas-Carbo, J. Flexas, J. Escalona, and H. Medrano, "UAVs challenge to assess water stress for sustainable agriculture," Agric. Water Manag., vol. 153, pp. 9-19, 2015. https://doi.org/10.1016/j. agwat. 2015.01.020
[24] Aerodreams, "Chi-7 productos," may 12th 2015 [Online]. Available: http://www. aerodreams-uav . com/

[25] A. Valencia, "Real Group Interactive," may 12th 2015 [Online]. Available: http: //www.realgroupinteractive.com

[26] GeoSpatial, "GeoSpatial soluciones espaciales para infrestructura," may 12 th 2015 [Online]. Available: http://www.geospatial.com.co/

[27] F. Escobar, "Advector s.a.s," may 12 th 2015 [Online]. Available: http://www.advector.co/

[28] J. Torres, F. López, and J. M. Peña, "An automatic object-based method for optimal thresholding in UAV images: Application for vegetation detection in herbaceous crops," Comput. Electron. Agric., vol. 114, pp. 43-52, 2015. https://doi .org/10.1016/j . compag. 2015.03.019

[29] J. Torres, J. M. Peña, A. I. de Castro, and F. López, "Multi-temporal mapping of the vegetation fraction in early-season wheat fields using images from UAV," Comput. Electron. Agric., vol. 103, pp. 104-113, 2014. https://doi.org/10.1016/j. compag. 2014.02.009

[30] C. A. Rokhmana, "The Potential of UAV-based Remote Sensing for Supporting Precision Agriculture in Indonesia," Procedia Environ. Sci., vol. 24, pp. 245-253, 2015. https://doi.org/10.1016/j. proenv.2015.03.032

[31] K. Shen, W. Li, Z. Pei, W. Fei, G. Sun, X. Zhang, $\mathrm{X}$. Chen, and S. Ma, "Crop Area Estimation from UAV Transect and MSR Image Data Using Spatial Sampling Method," Procedia Environ. Sci., vol. 26, no. 41301506, pp. 95-100, 2015. https://doi.org/ $10.1016 / j$. proenv .2015 .05 .007

[32] F. J. Mesas, M. D. Notario, J. E. Meroño de Larriva, M. Sánchez de la Orden, and A. García, "Validation of measurements of land plot area using UAV imagery," Int. J. Appl. Earth Obs. Geoinf., vol. 33, pp. 270-279, 2014. https://doi.org/10.1016/ $j \cdot j \mathrm{ag} .2014 .06 .009$

[33] Y. Lin, M. Jiang, Y. Yao, L. Zhang, and J. Lin, "Use of UAV oblique imaging for the detection of individual trees in residential environments," Urban For. Urban Green., vol. 14, no. 2, pp. 404-412, 2015. https://doi.org/10.1016/j.ufug.2015.03.003

[34] J. A. Gonçalves and R. Henriques, "UAV photogrammetry for topographic monitoring of coastal areas," ISPRS J. Photogramm. Remote 
Sens., vol. 104, pp. 101-111, 2015. https: //doi.org/10.1016/j.isprsjprs.2015.02.009

[35] J. Bendig, K. Yu, H. Aasen, A. Bolten, S. Bennertz, J. Broscheit, M. L. Gnyp, and G. Bareth, "Combining UAV-based plant height from crop surface models, visible, and near infrared vegetation indices for biomass monitoring in barley," Int. J. Appl. Earth Obs. Geoinf., vol. 39, pp. 79-87, 2015. https://doi. org/10.1016/j.jag.2015.02.012

[36] P. J. Zarco, R. Diaz, V. Angileri, and P. Loudjani, "Tree height quantification using very high resolution imagery acquired from an unmanned aerial vehicle (UAV) and automatic 3D photo-reconstruction methods," Eur. J. Agron., vol. 55, pp. 89-99, 2014. https://doi.org/10.1016/j.eja.2014.01.004

[37] P. J. Zarco, M. L. Guillén, R. Hernández, A. Catalina, M. R. González, and P. Martín, "Estimating leaf carotenoid content in vineyards using high resolution hyperspectral imagery acquired from an unmanned aerial vehicle (UAV)," Agric. For. Meteorol., vol. 171-172, pp. 281-294, 2013. https: //doi.org/10.1016/j.agrformet.2012.12.013

[38] M. Uysal, A. S. Toprak, and N. Polat, "DEM generation with UAV Photogrammetry and accuracy analysis in Sahitler hill," Measurement, vol. 73, pp. 539-543, 2015. https://doi.org/10.1016/j. measurement.2015.06.010

[39] P. K. Freeman and R. S. Freeland, "Politics \&amp; technology: U.S. polices restricting unmanned aerial systems in agriculture," Food Policy, vol. 49, pp. 302-311, 2014. https://doi.org/10.1016/j. foodpol.2014.09.008

[40] J. Straub, "Unmanned aerial systems: Consideration of the use of force for law enforcement applications," Technol. Soc., vol. 39, pp. 100-109, 2014. https://doi.org/10.1016/j.techsoc. 2013.12.004

[41] C. Pinilla, "Actualizaciones catastrales mediante teledetección," in 1st International Congress on Unified and Multipurpose Cadastre, 2010, pp. 1-4.

[42] S. P. Bemis, S. Micklethwaite, D. Turner, M. R. James, S. Akciz, S. T. Thiele, and H. A. Bangash, "Ground-based and UAV-Based photogrammetry: A multi-scale, high- resolution mapping tool for structural geology and paleoseismology," J. Struct. Geol., vol. 69, pp. 163-178, 2014. https://doi.org/ $10.1016 / j \cdot j s g .2014 .10 .007$
[43] S. Siebert and J. Teizer, "Mobile 3D mapping for surveying earthwork projects using an Unmanned Aerial Vehicle (UAV) system," Autom. Constr., vol. 41, pp. 1-14, 2014. https://doi.org/10.1016/j. autcon. 2014.01 .004

[44] K. D. Peter, S. d'Oleire-Oltmanns, J. B. Ries, I. Marzolff, and A. Ait Hssaine, "Soil erosion in gully catchments affected by land-levelling measures in the Souss Basin, Morocco, analysed by rainfall simulation and UAV remote sensing data," Catena, vol. 113, pp. 24-40, 2014. https://doi.org/10.1016/j.catena. 2013.09 .004

[45] DANE, "Manual de uso de fotografía aérea y cartografía topográfica," pp. 1-68, 2013.

[46] S. Yahyanejad and B. Rinner, "A fast and mobile system for registration of low-altitude visual and thermal aerial images using multiple small-scale UAVs," ISPRS J. Photogramm. Remote Sens., vol. 104, pp. 189-202, 2015. https://doi.org/10.1016/ j.isprsjprs.2014.07.015

[47] H. Xiang and L. Tian, "Method for automatic georeferencing aerial remote sensing (RS) images from an unmanned aerial vehicle (UAV) platform," Biosyst. Eng., vol. 108, no. 2, pp. 104-113, 2011. https://doi .org/10.1016/j.biosystemseng . 2010.11 .003

[48] A. Matese, F. Capraro, J. Primicerio, G. Gualato, S. F. Di Gennaro, and G. Agati, "Precision agriculture '13," pp. 201-208, 2013.

[49] R. Ballesteros, J. F. Ortega, D. Hernández, M. A. Moreno, "Applications of georeferenced high-resolution images obtained with unmanned aerial vehicles. Part I: Description of image acquisition and processing," Precis. Agric, vol. 15, pp. 579-592, 2014. https://doi.org/10.1007/ s11119-014-9355-8

[50] C. Li, G. Zhang, T. Lei, and A. Gong, "Quick image-processing method of UAV without control points data in earthquake disaster area," Trans. Nonferrous Met. Soc. China, vol. 21, pp. s523-s528, 2011. https://doi.org/10.1016/S1003-6326(12) 61635-5

[51] M. L. Guillen, P. J. Zarco, J. J. Berni, P. R. J. North, and F. J. Villalobos, "Mapping radiation interception in row-structured orchards using $3 \mathrm{D}$ simulation and high- resolution airborne imagery acquired from a UAV," Precis. Agric., vol. 13, no. 4, pp. 473-500, 2012. https://doi.org/10.1007/ s11119-012-9263-8 
[52] H. Xiang and L. Tian, "Development of a low-cost agricultural remote sensing system based on an autonomous unmanned aerial vehicle (UAV)," Biosyst. Eng., vol. 108, no. 2, pp. 174-190, 2011. https://doi.org/10.1016/j.biosystemseng. 2010.11.010

[53] B. S. Faiçal, F. G. Costa, G. Pessin, J. Ueyama, H. Freitas, A. Colombo, P. H. Fini, L. Villas, F. S. Osório, P. a. Vargas, and T. Braun, "The use of unmanned aerial vehicles and wireless sensor networks for spraying pesticides," J. Syst. Archit., vol. 60, no. 4, pp. 393-404, 2014. https://doi.org/ $10.1016 / j$. sysarc . 2014.01 .004

[54] D. Gómez, A. I. De Castro, and F. López, "Assessing the accuracy of mosaics from unmanned aerial vehicle (UAV) imagery for precision agriculture purposes in wheat," Precis. Agric., vol. 15, no. 1, pp. 44-56, 2014. https://doi.org/10.1007/s11119-013-9335-4

[55] L. A. Perilla and A. M. Sanabria, "Condiciones que favorecen el desarrollo del mildeo polvoso (Aphaerotheca pannosa var rosae) en los cultivos de rosa de la sabana de Bogotá," Tesis de grado para optar por el título de microbiólogo agrícola y veterinario, Universidad Javeriana, Facultad de ciencias, Bogotá, Colombia, 2007.

[56] R. Calderón, M. Montes, B. B. Landa, J. a. Navas-Cortés, and P. J. Zarco-Tejada, "Detection of downy mildew of opium poppy using high-resolution multi-spectral and thermal imagery acquired with an unmanned aerial vehicle," Precis. Agric., vol. 15, no. 6, pp. 639-661, 2014. https://doi.org/10.1007/ s11119-014-9360-y

[57] UPRM, "Sintomas visuales de deficiencias nutricionales (Diagnostico visual)," june 12 th 2015. [Online]. Available: http://academic.uprm. edu/dsotomayor/agro4037/handouts/Sintomas_ visuales.pdf

[58] R. Melchiori, A. Kemerer, and S. Albarenque, "Uso de un UAV para el diagnóstico del estado de nutrición nitrogenada en maíz," EAA INTA Paraná, 2012.

[59] M. Zaman-Allah, O. Vergara, J. L. Araus, a Tarekegne, C. Magorokosho, P. J. Zarco- Tejada, a Hornero, a H. Albà, B. Das, P. Craufurd, M. Olsen, B. M. Prasanna, and J. Cairns, "Unmanned aerial platform-based multi-spectral imaging for field phenotyping of maize," Plant Methods, vol. 11, no. 1, p. 35, 2015. https://doi.org/10.1186/ s13007-015-0078-2
[60] F. A. Vega, F. C. Ramírez, M. P. Saiz, and F. O. Rosúa, "Multi-temporal imaging using an unmanned aerial vehicle for monitoring a sunflower crop," Biosyst. Eng., vol. 132, pp. 19-27, 2015. https:// doi.org/10.1016/j. biosystemseng. 2015.01.008

[61] L. Comba, P. Gay, J. Primicerio, and D. Ricauda Aimonino, "Vineyard detection from unmanned aerial systems images," Comput. Electron. Agric., vol. 114, pp. 78-87, 2015. https://doi.org/10. 1016/j. compag. 2015.03.011

[62] P. Chamoso, W. Reveane, V. Parra, and A. Gonzáles, "UAVs applied to the counting and monitoring of animals", ambient intelligence-software and application, vol. 291. 2014. https://doi.org/ 10.1007/978-3-319-07596-9_8

[63] S. Herwitz, L. Johnson, S. Dunagan, R. Higgins, D. Sullivan, J. Zheng, B. Lobitz, J. Leung, B. Gallmeyer, M. Aoyagi, R. Slye, and J. Brass, "Imaging from an unmanned aerial vehicle: agricultural surveillance and decision support," Comput. Electron. Agric., vol. 44, no. 1, pp. 49-61, 2004. https://doi.org/10. 1016/j. compag. 2004.02 .006

[64] V. Gonzalez, D. Goldhamer, P. J. Zarco, and E. Fereres, "Improving the precision of irrigation in a pistachio farm using an unmanned airborne thermal system," Irrig. Sci., vol. 33, no. 1, pp. 43-52, 2015. https://doi.org/10.1007/s00271-014-0447-z

[65] A. Royuela, J. Manzano, and D. Intrigliolo, "Assessment drip irrigation sub-units using airborne thermal acquire with an Unmaned Aerial Vehicle (UAV)," in Springer link, no. Instituto Valenciano de Investigaciones Agrarias, J. V. Stafford, Ed. Wageningen Academic Publishers, 2013, pp. 705-711.

[66] J. Bellvert, P. J. Zarco, J. Girona, and E. Fereres, "Mapping crop water stress index in a 'Pinot-noir' vineyard: comparing ground measurements with thermal remote sensing imagery from an unmanned aerial vehicle," Precis. Agric., pp. 1-16, 2013.

[67] V. Gonzalez, P. Zarco, E. Nicolás, P. a. Nortes, J. J. Alarcón, D. S. Intrigliolo, and E. Fereres, "Using high resolution UAV thermal imagery to assess the variability in the water status of five fruit tree species within a commercial orchard," Precis. Agric., vol. 14, pp. 660-678, 2013. https://doi.org/10.1007/ s11119-013-9322-9

[68] P. J. Zarco, V. González, and J. A. J. Berni, "Fluorescence, temperature and narrow- band indices acquired from a UAV platform for water stress detection using a micro- hyperspectral imager and a 
thermal camera," Remote Sens. Environ., vol. 117, pp. 322-337, 2012. https://doi.org/10.1016/j. rse. 2011.10 .007

[69] J. Baluja, M. P. Diago, P. Balda, R. Zorer, F. Meggio, F. Morales, and J. Tardaguila, "Assessment of vineyard water status variability by thermal and multispectral imagery using an unmanned aerial vehicle (UAV)," Irrig. Sci., vol. 30, no. 6, pp. 511-522, 2012. https://doi.org/10.1007/ s00271-012-0382-9
[70] R. A. Zahawi, J. P. Dandois, K. D. Holl, D. Nadwodny, J. L. Reid, and E. C. Ellis, "Using lightweight unmanned aerial vehicles to monitor tropical forest recovery," Biol. Conserv., vol. 186, pp. 287-295, 2015. https://doi.org/10.1016/j. biocon.2015.03.031

[71] Red de especialistas en agricultura, june 12 th 2016, [Online] Available: HYPERLINK 